\title{
DEBATE TRANSFORMADO EM QUERELA: PANORAMA SOBRE A RELAÇÃO ENTRE O LUXO E AS PAIXÕES
}

\author{
Rafael de Araújo e Viana Leite ${ }^{1}$ \\ Universidade Federal do Paraná (UFPR) \\ (iD) https://orcid.org/0000-0002-1676-6428
}

RESUMO:

Pretendo mostrar a relação entre o surgimento das primeiras apologias do luxo no século XVIII e a mudança de estatuto das paixões humanas. A hipótese que gostaria de defender é a de que a alteração da compreensão das paixões humanas possibilitou a formulação de uma nova antropologia segundo a qual a busca por prazer é entendida como legítima moral e politicamente.

PALAVRAS-CHAVE: Luxo; Moral; Paixões; Iluminismo.

\section{A DEBATE TURNED INTO A QUARREL: OUTLINE ON THE RELATION BETWEEN LUXURY AND PASSIONS}

\begin{abstract}
:
The aim of this paper is to show the link between the first luxury apologies in the eighteenth-century and the change of status of passions. The hypothesis I would like to defend is that the new approach on passions made possible the rising of a new anthropology in which the search for pleasure is accepted as legitim in political as well as in moral terms.
\end{abstract}

KEYWORDS: Luxury; Moral; Passions; Enlightenment.

\footnotetext{
${ }^{1}$ Doutorando em Filosofia pela Universidade Federal do Paraná (UFPR), Paraná - Brasil. Bolsista CAPES. E-mail: rafael_vianaleite@hotmail.com

LEITE, Rafael de Araújo e Viana. Debate transformado em querela: panorama sobre a relação entre o luxo e as paixões. Griot : Revista de Filosofia, Amargosa/Bahia, v.17, n.1, p.33-47, junho/2018. 
De fato, o exame da querela do luxo mostra-se exemplar para se tentar compreender o conjunto das transformações conceituais operadas entre os fins do século XVII e XVIII, pelo menos em sua generalidade, já que expressa, às vezes direta, às vezes indiretamente, a lenta mutação e constituição das novas concepções (sobre o desejo e prazer). (MONZANI, 2011, p. 22).

Este artigo é etapa de uma pesquisa mais ampla. Seu objetivo é fazer um panorama introdutório sobre a disputa filosófica em torno do luxo. Mais especificamente, sobre a relação entre o aparecimento das primeiras apologias do luxo no século XVIII e uma mudança conceitual, lentamente realizada, a propósito das paixões humanas e seu impacto na moral e na política. Estamos diante de um amplo quadro histórico, de modo que exclusões importantes serão necessariamente percebidas pelo leitor. Contudo, espera-se que essa lacuna seja minimamente compensada pela escolha de autores cuja contribuição foi importante para entender a mudança de estatuto das paixões humanas a respeito da qual trataremos.

Atualmente, na maior parte das sociedades ocidentais, é inegável que o luxo seja aceito e bastante procurado. Caracterizações de produtos ou serviços como 'luxe' ou 'deluxe' são consideradas como traços positivos. A busca por prazer e comodidades é vista como legítima. Não foi, porém, repentinamente que a crítica de, por exemplo, Platão, Sêneca e La Bruyère e tantos outros moralistas passassem a ser questionadas. $O$ objetivo deste artigo não é tentar dar uma resposta unívoca, forçosamente simplista, para um processo longo e complexo, porém, fazer um panorama inicial das mudanças conceituais em torno da avaliação moral sobre as paixões humanas capazes, segundo me parece, de provocar uma importante alteração no debate sobre o luxo, fazendo com que ele se transformasse em uma verdadeira querela, dando possiblidade para que sua defesa filosófica fosse feita de maneira consistente.

Não é preciso muito esforço para defender que o luxo é um tema filosófico. Defendê-lo ou criticá-lo implica em uma tomada de posição ética, política ou mesmo estética. Se uma resposta como essa não for suficiente, bastaria considerar a ampla história de sua crítica ou as tentativas para justificá-lo politicamente para perceber como esse tema impulsionou muitas reflexões. Sua defesa, ao menos uma que fosse consistente, apoiada em termos morais e econômicos, veio somente no século XVIII, com Bernard Mandeville e seu poema intitulado The grumbling hive, or knaves turn'd honests de 1705. Posteriormente, sua posição foi desenvolvida com a publicação da obra The fable of the bees: or, private vice, publick benefits, cuja primeira edição apareceu em 1714. Podemos dizer que essa obra abriu um caminho continuamente alongado.

Não muito tempo depois da obra de Mandeville apareceram outras obras, mais ou menos próximas da Fábula das abelhas, responsáveis por propor a defesa do luxo, como foi o caso do Essai politique sur le commerce, de Jean-François Melon, em 1734, e alguns textos de Voltaire, por exemplo, dos importantes poemas Le mondain e Défense du mondain, de 1736 e 1737. Algo aconteceu para que essas apologias se multiplicassem no século XVIII depois de uma longa história de críticas e ressalvas. Mas o que houve? É com essa questão que nos defrontaremos.

LEITE, Rafael de Araújo e Viana. Debate transformado em querela: panorama sobre a relação entre o luxo e as paixões. Griot 
Sobre o debate sobre o luxo antes do século XVIII, duas características merecem destaque. Primeiro, sua antiguidade ${ }^{2}$. Quem sabe o luxo exista desde o momento em que alguém tenha resolvido cortar suas franjas e encontrou conservadores para lhe censurar, como diz jocosamente Voltaire, na seção II do verbete Luxo, presente em seu Dicionário filosófico (online). Não nos esqueçamos, além disso, do relato de Heródoto sobre o general espartano Pausânias a respeito do seu estranhamento para com o luxo dos persas derrotados em Plateia ${ }^{3}$. A Esparta de Licurgo quando renegou o luxo (Plutarco nos conta como a circulação de ouro era proibida), deixou para os moralistas um modelo de virtude austera que será retomado repetidamente ${ }^{4}$. Diógenes, o Cínico, foi protagonista de algumas histórias contadas por Diógenes Laércio bastante ilustrativas. Uma das anedotas mais eloquentes sobre nosso tema trata do momento em que o filósofo cínico se livrou de sua vasilha de madeira ao ver uma criança tomando água somente com a ajuda de suas mãos ${ }^{5}$. Ensinamento emblemático de simplicidade.

Em segundo lugar, se muitos foram os pensadores que se viram às voltas com o cálculo envolvendo os benefícios e prejuízos do luxo, as críticas e ressalvas têm peso muito maior do que qualquer apologia ${ }^{6}$. Frequentemente, era atacado por favorecer a ganância e corromper a virtude, muitas vezes relacionado com o fausto de um governo despótico, era acusado por estimular paixões nocivas como inveja, orgulho e vaidade. A crítica ao luxo era, ademais, frequentemente política ou ainda moral.

\footnotetext{
${ }^{2}$ Baudrillart, em sua sua obra Histoire du Luxe Privé et Public depuis l'antiquité jusqu’à nos jours, de 1880, aborda o luxo desde os egípcios, passando pelos gregos até o século XIX.

${ }^{3}$ Ver a obra de Heródoto intitulada História, Livro IX. Parágrafo LXXXI. "Dizem que Xerxes, ao fugir da Grécia, deixara a Mardônio os utensílios que trouxera consigo na expedição: vasilhames de ouro e pratas e ricos tapetes de diversas cores; e que Pausânias, ao ver essas riquezas, ordenou aos cozinheiros de Mardônio que preparassem um banquete, como se fosse para seu amo (...) tomado de surpresa ante tão grande fausto e querendo divertir-se, ordenou a seus servos que lhe servissem uma ceia à maneira da Lacedemônia; e ao observar a enorme diferença entre o seu repasto e o que fizera preparar para Mardônio, não pôde deixar de rir. Mandando vir à sua presença os generais gregos, disse-lhes, apontando as duas mesas postas para o ágape: 'gregos, mandei-vos chamar para mostrarvos a estupidez do general dos persas, que, dispondo de tão boa mesa, aqui veio para privar-nos da nossa tão miserável." (HERÓDOTO, 2001, p. 431).

${ }^{4}$ Ver BAUDRILLART (1880, p. 33); HERÓDOTO, Livro IX, parágrafos 80-82; MONZANI (2011, p 23); e PLUTARCO (1951, Cap. XIII, p. 206).

5 "Um dia, observando uma criança bebendo água com a ajuda de suas mãos, jogou fora seu copo dizendo essas palavras: 'uma criança me superou em simplicidade de vida'. Ele também jogou sua vasilha quando, em situação semelhante, viu uma criança que tinha quebrado seu prato pegar suas lentilhas com o buraco feito no pão". (LAERTIUS, 2005, p. 39. Tradução minha).

6 "Lusso e avidità sono correlati dall'assenza di uma misura che li rende insaziabili e assorbono la personalità individuale alienandola da ogni dovere sai nella sfera privata che pubblica. Da qui il conflitto tra richezza e virtù largamente presente nel pensiero político e morale dall'antichità al XVIII secolo." (BARBINI, 2009, p. 26). Ver também, de Jean-Jacques Rousseau, o VII Fragmento Político, intitulado Le Luxe, le Commerce et les Arts: "Todos os antigos consideraram o luxo como signo de corrupção dos costumes e de fraqueza do governo. As leis sumptuárias são quase tão antigas quanto às sociedades políticas (...)" (ROUSSEAU, 1964, t. III, p. 517. Tradução minha). Também Voltaire concede neste ponto. Na seção II do verbete 'luxo' do Dicionário filosófico lemos que "Há dois mil anos o luxo vem sendo criticado, tanto em verso quanto em prosa, e foi sempre amado". (online. Tradução minha).
}

LEITE, Rafael de Araújo e Viana. Debate transformado em querela: panorama sobre a relação entre o luxo e as paixões. Griot : Revista de Filosofia, Amargosa/Bahia, v.17, n.1, p.33-47, junho/2018. 
Platão, ao escrever sobre a República ideal, tece várias críticas ao luxo. No Livro II da obra $A$ República, após iniciar a investigação sobre o valor e natureza da justiça e depois de estabelecer o método de investigação mais apropriado, o personagem Sócrates procede a uma espécie de gênese da cidade ideal ${ }^{7}$. Em diálogo com Adimanto, Sócrates expõe o motivo de formação da cidade, quem ali vive e qual seu ofício. Essa comunidade em vias de formação não é rica, pois simplesmente atende às necessidades básicas dos seus habitantes. A rotina dessas pessoas hipotéticas é bem frugal ${ }^{8}$. Diante disso, não demora até a intervenção de outro interlocutor, Glauco. Ele reclama mais comodidades para os habitantes dessa cidade imaginária ${ }^{9}$. Sócrates cede à intervenção de seu amigo e deixa entrar na cidade artigos luxuosos que não correspondem exatamente às necessidades básicas de uma pessoa. Vemos, assim, a introdução de pinturas, bordados, marfim e metais preciosos. Para entretenimento dos habitantes, colocam-se à sua disposição atores, dançarinos e poetas.

Sócrates, portanto, replica a intervenção de Glauco de forma condescendente, contudo, faz uma importante ressalva: “- Seja (...) examinemos não apenas uma cidade em formação, mas também uma cidade cheia de luxo. (...) Seja como for, a verdadeira cidade me parece aquela que descrevi como sã." (PLATÃO, 1965, 372d $373 b)$. O problema do luxo é que ele seria aliado da desigualdade e estimularia o gosto por riquezas, característica prejudicial do ponto de vista político. Temos diante de nós uma crítica cuja tese principal se ancora na tentativa de impedir a diferenciação indevida entre os cidadãos ${ }^{10}$.

Sêneca, por sua vez, em suas Cartas a Lucílio, propõe uma análise do fenômeno do luxo que poderíamos chamar de psicológica, apontando os infortúnios de quem é dominado pelo desejo insaciável por riquezas. Ele defende uma vida de moderação, mas não uma vida de austeridade completa. A crítica ao luxo se dirige mais explicitamente, para citar três exemplos, em sua manifestação abusiva na

\footnotetext{
7 Veremos explicitada a justiça tal como aparece na cidade - um âmbito macro, portanto, de mais fácil visualização, por assim dizer - para depois analisarmos a justiça no homem.

8 “Durante o verão, trabalhará a maior parte do tempo nu e descalço, durante o inverno, vestido e calçado convenientemente. Para se nutrir, preparará farinha de cevada e de frumento (...) disporá os magníficos bolos e pães sobre ramos ou folhas frescas (...) regalar-se-á em companhia da prole, bebendo vinho, com a cabeça coroada de flores e cantando louvores aos deuses; passará assim agradavelmente a vida em conjunto e regulará o número dos filhos segundo os recursos (...)" (PLATÃO, Livro II, 371e-372d, 1965).

9 Adimanto não se mostra satisfeito em relação a essa primeira elaboração da cidade e objeta: "- Se fundasse uma sociedade de porcos, Sócrates - disse - engordá-los-ia de outro modo?" (PLATÃO, 1965, Livro II 372d - 373b).

10 Nos Livros IV e VIII o luxo é colocado em uma relação frequentemente retomada pelos seus detratores: ele iria de par com a corrupção da virtude e desigualdade entre os cidadãos. Sócrates ainda adverte para que não se deixe insinuar na cidade a desigualdade em forma de riqueza/pobreza, pois, uma engendra o luxo, a preguiça e o gosto pelas novidades enquanto a outra daria vazão à baixeza e à perversidade. (421e - 422d). Já no Livro VIII, Sócrates coloca o apreço pela virtude e o desejo pela riqueza em uma relação inversamente proporcional, não sem antes ter feito restrições ao uso do dinheiro por parte dos habitantes da cidade. Em nome da virtude cívica e igualdade, a cidade ideal não possui propriedade particular e é cautelosa quanto ao comércio. Se o luxo é permitido, aconselhase moderação quando de seu uso, pois ele é fonte de corrupção moral ao dar vazão à ganância e desejo de lucro em lugar de os homens ostentarem - pelo contrário - sentimentos cívicos em prol do bem comum.
}

LEITE, Rafael de Araújo e Viana. Debate transformado em querela: panorama sobre a relação entre o luxo e as paixões. Griot : Revista de Filosofia, Amargosa/Bahia, v.17, n.1, p.33-47, junho/2018. 
culinária, isto é, em uma gulodice sem limites: "Repara em nossas cozinhas e nos cozinheiros que se atropelam à roda de todos os fogões: parece-te plausível que tanta agitação se destine a preparar comida para um único estômago?" (SÊNECA, 2001, p. 637). No vestuário quando não passa de uma ostentação insensata e ainda na decoração inútil da casa ${ }^{11}$.

Se o objetivo do filósofo estoico, de maneira geral, é atingir a ataraxia, ou seja, a independência em relação às paixões, o gozo do luxo facilmente pode ser visto como obstáculo para a virtude: “(...) quando a alma cede ao império do prazer, os nossos talentos e as nossas ações degradam-se, todos os nossos esforços carecem por completo de consistência." (SÊNECA, 2001, p. 636). Chegamos em um ponto importante. A busca por prazer e pelo luxo é prejudicial, pois deve-se controlar as paixões em nome da moderação. Assim, o estoico defende que devemos saber tirar do ouro e das riquezas o melhor proveito possível, e isso se obtêm paradoxalmente quando os possuímos e não necessitamos deles ${ }^{12}$. Em se tratando da obtenção da virtude, Sêneca prescreve a ausência de paixões como a avareza, vaidade, ambição ou inveja, aliadas das riquezas e do luxo ${ }^{13}$.

Não foram apenas críticas, entretanto, lançadas contra o luxo. Ele também foi considerado como um signo político que marcaria uma desigualdade social tida por legítima. Em outras palavras, seria aceitável em alguns âmbitos sociais como entre a realeza, o meio militar e clerical. Parece ser em tais bases que Tomás de Aquino defende a sua exclusividade. Na Suma Teológica, especificamente na questão CLXIX, o filósofo considera o possível vício ou virtude ligado às vestimentas e adornos. A premissa parece ser a de que a vestimenta e o ornamento não seriam naturais, bastaria levar em conta a sua contingência e variabilidade conforme a diversidade dos tempos e dos lugares (1958, p. 1018). Pautados por uma conduta de simplicidade, cabe às pessoas não abusar dos ornamentos e vestes, pois assim estarão exercendo culto ao corpo, sendo escravos das paixões, no caso, a vanglória (1958, p. 1020).

A conclusão é a de que as vestimentas e ornamentos são neutros moralmente. Isso quer dizer que o vício residiria propriamente no uso abusivo que se faz deles: "As coisas exteriores, em si mesmas, de que o homem usa não são matéria de nenhum vício, que só existe em quem as emprega imoderadamente." (AQUINO, 1958, p. 1020). Os adereços não são viciosos neles mesmos, entretanto, isso pouco importa já que não se deve utilizá-los em nome da moderação. Além disso, pecam todos aqueles que produzem tais supérfluos por seu engenho, pois dão ocasião para outros pecarem (1958, p. 1032).

\footnotetext{
11 Vale ainda dizer que, para Sêneca, quando o gosto sadio é substituído pelo luxo, a moral não tardaria a se corromper: "Por conseguinte, sempre que veres um estilo decadente cair nas boas graças do público, podes estar certo de que a moralidade anda também muito por baixo! Assim como o luxo excessivo nos banquetes ou no modo de se vestir é sintoma de uma sociedade doente, também o barroquismo do estilo, quando se generaliza, mostra que os espíritos estão decadentes." (SÊENECA, 2001, p. 632).

12 Ver a Carta XIV (2001, p. 49).

${ }^{13}$ Uma vez que a busca por prazer é engatilhada a ânsia por comodidades nunca é satisfeita e, desse modo, querendo sempre aumentar os bens materiais, reféns de um desejo que nunca se satisfaz, vemos ser dada a partida a um ciclo vicioso constituído pelo desejo, obtenção do desejado, satisfação temporária, novamente desejo, etc.
}

LEITE, Rafael de Araújo e Viana. Debate transformado em querela: panorama sobre a relação entre o luxo e as paixões. Griot : Revista de Filosofia, Amargosa/Bahia, v.17, n.1, p.33-47, junho/2018. 
Em Tomás de Aquino a crítica ao luxo parece ser moral, dirigida principalmente aos particulares, cujo vestuário deveria corresponder à condição da pessoa e estar em conformidade com os costumes vigentes. Ele será permitido, porém, quando colocado a serviço de Deus, como ferramenta ritual seja em cerimoniais litúrgicos ou ainda quando usado por dignidades político-militares. Nesses termos, seria o signo dos diferentes estamentos sociais legitimados por Deus. Em certo sentido, ratificador da desigualdade entre os homens. Como diz o próprio Tomás de Aquino em sua defesa do luxo como signo exclusivo de certas classes:

Os constituídos em dignidade, ou ainda os ministros do altar, usam de roupagens mais preciosas que os outros, não para a glória, mas para exprimir-lhes a excelência do ministério ou do culto divino. Por isso, não

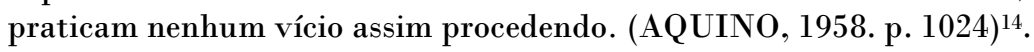

Temos a utilização de uma argumentação distinta da tradição anterior. $O$ luxo seria prejudicial ao particular, pois se trata de um vício, portanto, é pecado se submeter a paixões como a vaidade. Entretanto, há margem para um uso políticosimbólico dele. Essa incursão panorâmica a alguns textos clássicos sobre o luxo busca preparar o terreno para que possamos ressaltar uma mudança conceitual operada definitivamente no século XVIII. Antes do iluminismo, porém, Montaigne fez várias críticas aos costumes dos europeus, além de questionar o luxo justamente enquanto signo político-moral, tal qual aceito por Aquino.

Vejamos o capítulo XXXI dos Ensaios, quando Montaigne contrapõe o canibal ao homem civilizado. $O$ primeiro não sairia perdendo, pois seus costumes são simples, menos corrompidos pelas novidades e pelo luxo: "(...) têm ademais a felicidade de limitar seus desejos ao que exige a satisfação de suas necessidades naturais, tudo o que as excede lhes parecendo supérfluo." (MONTAIGNE, 1980. p. 104). Já não estamos em um registro que permita nuances como 'excesso de luxo', tal qual foi visto em Sêneca. Luxo é justamente o excedente, ou melhor, aquilo que ultrapassa o necessário para a subsistência. Supérfluo se definiria assim pelas coisas que vão além da necessidade básica. Voltemos ao texto intitulado Dos canibais. Um dos aspectos que mais teriam surpreendido os índios na sociedade europeia foi o fato de existirem pessoas gozando da abundância, muito bem alimentadas, enquanto outras passavam sem o necessário. O que mais interessa nesse exemplo é que agora a desigualdade volta a aparecer como algo negativo resultado do luxo.

A novidade da tese de Montaigne sobre nosso assunto se encontra totalmente delineada no cap. XXXVI dos Ensaios, Do hábito de se vestir. Montaigne se vale sintomaticamente do mesmo exemplo de Aquino ao apontar como as roupas não seriam naturais, contudo, ainda assim são necessárias para nos protegermos das intempéries. $O$ problema é que ao início pautado pela necessidade se juntaria o nãonatural, ou seja, o supérfluo e o artificial. Com roupas de diferentes cores e formas, adornadas com diferentes apetrechos, ultrapassaríamos o necessário porque seríamos levados pelo excesso: "Mas assim como há quem use a luz artificial que enfraquece a luz do dia, enfraquecemos a eficiência dos meios naturais que nos protegem

14 “Uma certa desigualdade nas condições, que mantém a ordem e a subordinação, é obra de Deus, ou supõe uma lei divina. Uma desproporção excessiva, e tal que humanamente se nota, é obra dos homens, ou provém da lei do mais forte." (AQUINO, 1958, p. 240).

LEITE, Rafael de Araújo e Viana. Debate transformado em querela: panorama sobre a relação entre o luxo e as paixões. Griot 
substituindo-os por outros artificiais" (MONTAIGNE, 1980. p. 110). Tudo isso bem próximo de Aquino.

O ponto de afastamento central parece ser a crítica ao luxo enquanto ferramenta política. Falando sobre a desigualdade entre os homens, Montaigne indica como as diferenças de indumentária que nos saltam aos olhos quando da imagem de um camponês e de um rei não são essenciais, ou seja, não dizem respeito a uma diferença de caráter ou mérito. Montaigne aceita a desigualdade quanto às características intelectuais, no entanto, as pessoas se assemelhariam entre si a partir de um importante aspecto. Seríamos todos submetidos pelas paixões, sofrimentos e inconstâncias da vida.

Quando se fala de luxo, elemento capaz de distinguir as pessoas, não são os fatos ou atributos essenciais, mas a imaginação que tem predomínio. Inferimos a qualidade do falcão, diz Montaigne, pelo voo e não pela coleira. $\mathrm{O}$ cavalo pelo vigor $\mathrm{e}$ rapidez antes do que pelo arreio, por que, pergunta o autor, apreciamos os homens pelas qualidades específicas? (1980, Cap. XLII, p. 124). As pessoas se valem do luxo, podemos dizer, justamente para disfarçar quem realmente são ${ }^{15}$.

O luxo é abordado enquanto um signo. Seu uso se confunde com a tentativa de nos remeter a certo significante responsável por impor uma diferenciação entre as pessoas. A crítica de Montaigne, no limite, aponta para o fato de que o rei, por vezes, parece ser feito simplesmente pela coroa e não por algum traço de liderança. Dito de outro modo, é a imaginação das pessoas que estipula o valor desse signo em si mesmo vazio. Ora, além de ser um objeto que pesa sobre a cabeça de alguém a coroa não reflete a essência do rei. Uma vez que as coisas passam a ser colocadas com tais termos, pode-se perguntar pela legitimidade da pessoa em relação ao cargo:

Esse imperador, por exemplo, cuja pompa em público nos ofusca, "porque brilham nele, engastadas em ouro, grandes esmeraldas da mais linda água, vestidos de magníficos trajes verde-mar que não tardará em sujar nas orgias e nos baixos prazeres', ide espiá-lo atrás da cortina: é apenas um homem vulgar, por vezes mais vil do que a maioria dos outros.' (MONTAIGNE, 1980, p. 125).

A questão da desigualdade social é abordada enquanto um problema. O tema das paixões, importa notar, vai mudando de figura. Elas já não são rechaçadas como simples obstáculos, inflamadas por nossa fraqueza, pois fazem parte da natureza humana. Essa perspectiva é central para nossos propósitos. Nesse sentido, La Bruyère torna-se emblemático. No século XVII, ele traça críticas que vão ao encontro das teses de Montaigne e de certa forma intensifica a revalorização das paixões humanas. Em relação ao uso do luxo e das riquezas, importa notar, faz comentários bastante pessimistas a propósito dos tempos modernos ${ }^{16}$.

\footnotetext{
15 "Nada do que nos mostra é dele e ele esconde tudo o que pode esclarecer-nos a seu respeito. O que precisamos saber é quanto vale a espada e não a bainha, porquanto talvez não demos grande coisa por ela. É necessário julgar o homem em si e não pelos adornos." (MONTAIGNE, 1980, p. 124).

16 “(...) que longe estamos de nossos antepassados! Não se privavam eles do necessário para possuir o supérfluo, nem preferiam o luxo às coisas úteis. Não saiam de um jantar para se pavonear em seu carro: - persuadiam-se de que o homem, se tinha pernas, era pra andar, e andavam." (LA BRUYÈRE, 1956, p. 121).
} 
Para o momento, gostaria de ressaltar o fato de que La Bruyère questiona a riqueza como ponte de acesso fácil à felicidade, semelhante ao que vimos em Sêneca. Questiona ainda o significante (felicidade, virtude, dignidade política) ao analisar o signo (luxo, pompa, fausto), como será feito por Rousseau no Discurso sobre as ciências $e$ as artes. O luxo enquanto ferramenta política também é severamente criticado ${ }^{17}$. Para tanto, questiona-se a validade do julgamento moral feito a partir das riquezas: “Um homem é feio, tem má figura, e é pouco inteligente. Dizem-me: tem cinquenta mil libras de rendimento! Acredito. Mas será isso motivo para eu começar a vê-lo com outros olhos?" (LA BRUYÈRE, 1965, p. 98). Temos desassociado, assim, o mérito da riqueza e hereditariedade ${ }^{18}$. Além disso, um gosto simples figurado em trajes modestos, de acordo com o autor, seria mais atraente do que esconder-se por detrás de adereços e muita pompa ${ }^{19}$.

La Bruyère, ainda próximo de Sêneca, também enfatiza os infortúnios de quem é rico, ou seja, das implicações psicológicas negativas do luxo. O homem rico e cheio de atribulações, cuidando mais de fazer fortuna do que de aproveitar a que está disponível acaba passando a vida a acumular comodidades que serão usufruídas pelos que vierem depois dele (1956, p. 106). As riquezas, portanto, poderiam causar mais problemas e preocupações do que melhorariam nossa vida ${ }^{20}$.

A relação entre luxo e falta de virtude é estabelecida, como foi feito em Platão. La Bruyère também critica o uso político do luxo e a disseminação da desigualdade entre as pessoas, como vimos em Montaigne. A novidade que nos interessa encontra-se na valoração das paixões. La Bruyère parece ser mais radical em relação a esse ponto. O controle racional, é verdade, seria importante caso queiramos manter uma boa conduta ${ }^{21}$. Contudo, a severidade da censura às paixões é muito atenuada. Elas não só fariam parte de nossa natureza, ainda que devamos

\footnotetext{
17 "É política segura e antiga essa de adormecer o povo por meio de festas, de espetáculos, de luxo, de fausto, de prazeres, de vaidade e de moleza; de deixá-lo viver de vácuo, e saborear as coisas insignificantes. Quantos louvores se tecem ao despotismo por tal indulgência!" (LA BRUYÈRE, 1956, p. 123).

18 "Há muitas pessoas de quem só o nome vale alguma coisa. Quando as vemos de muito perto, ainda valem menos; de longe têm certa aparência." (LA BRUYĖRE, 1956, p. 131).

19 “Um exterior simples é o traje dos homens vulgares, talhado para eles, à sua medida; mas é um adorno para aqueles que praticaram na vida grandes ações. Comparo-o a uma beleza descuidada, mas mais atraente." (LA BRUYÈRE, 1956, p. 35). Mais à frente, no capítulo Das mulheres, o autor critica veementemente a maquiagem que distorce o rosto das mulheres, tornando-as, segundo o autor, feias. 20 "Há almas vis, almas de lama, ávidas de ganho e de interesse, como as almas nobres o são de glória e de virtude; para elas só há uma volúpia, que é a de acumular sempre, e de nunca perder (...) sempre inquietas com a possível desvalorização da moeda; enfronhadas e perdidas nos títulos e contratos, e em papéis. Pessoas assim, não possuem o sentimento da família, não são amigos, nem cidadãos, nem cristãos, nem talvez mesmo homens: têm dinheiro." (LA BRUYÈRE, 1956, p. 110).

21 "Só na sua finalidade reside o merecimento das ações dos homens, e no desinteresse a sua perfeição." (LA BRUYĖRE, 1956, p. 42). “O homem sensato não se deixa dirigir, nem procura governar os outros: quer que a razão sempre o oriente." (LA BRUYÈRE, 1956, p. 72).
}

LEITE, Rafael de Araújo e Viana. Debate transformado em querela: panorama sobre a relação entre o luxo e as paixões. Griot 
almejar melhorias em nossa conduta, como elas nos seriam naturais ${ }^{22}$. Não podemos simplesmente suprimi-las ${ }^{23}$.

La Bruyère, confirmando nossa hipótese, critica tanto o ideal contido na obra $A$ República quanto a postura estoica de Sêneca justamente porque pressuporiam a possibilidade de se abafar completamente as paixões ${ }^{24}$. Estamos acompanhando uma importante mudança de perspectiva, central para nosso objetivo. As paixões deixam de ser consideradas como obstáculos iminentes para o bom uso da razão porque elas são consideradas naturais aos homens e é preciso tolerá-las, trabalhar com elas, administrá-las politicamente. Nossa hipótese é a de que essa mudança foi uma das forças motrizes que permitiram posteriormente a formulação, no século XVIII, de uma antropologia a partir da qual a busca por prazer é vista como um objetivo legítimo. Ponto basilar para a apologia do luxo.

Bernard Mandeville levará às últimas consequências a tese de La Bruyère. Se as paixões são naturais ao homem e, mais do que isso, se é impossível superá-las por completo, toda moral que pressuponha seu abafamento para alcance da virtude mostrar-se-á ilusória ${ }^{25}$. Thomas Hobbes também contribuiu para a reabilitação das paixões ao retirar a vaidade do limbo moral e colocá-la como característica marcante de sua antropologia ${ }^{26}$. Condillac, ele também, com sua teoria sensualista encara as paixões como sendo frutos de um processo sensível natural. Condillac não estabelece mais a dicotomia entre razão e paixão.

No século XVIII vemos explicitadas definitivamente algumas alterações conceituais que terão implicações no debate sobre o luxo, intensificando uma disputa

22 “Ninguém se indigne contra os homens pela sua dureza, pela sua ingratidão, pela sua injustiça, pela sua arrogância, pelo seu egoísmo, pelo seu desprezo dos outros. São assim feitos, são esses os seus defeitos, e não os suportar é como não querer que a pedra caia ou a chama se erga." (LA BRUYĖRE, 1956, p. 143).

23 "Custa pouco à paixão colocar-se acima da razão: o seu maior triunfo é o de vencer o interesse. Somos mais sociáveis e mais abordáveis pelo lado do coração do que pelo espírito." (LA BUYĖRE, 1956, p. 72).

24 “O estoicismo é um divertimento do espírito e uma ideia semelhante à da República de Platão. Os estoicos inventaram que na pobreza se conservava o bom humor; que se podia ser insensível às injúrias, à ingratidão, à perda da fortuna (...) que a morte devia ser olhada friamente, como coisa que não nos deve nem alegrar nem entristecer; que o prazer e a dor não nos impressionariam nem venceriam (...) a tal fantasma de virtude e de constância, aprouve-lhes dar o nome de filósofo." (LA BRUYÈRE, 1956, p. 143).

${ }^{25}$ Ver o diálogo escrito por Mandeville, presente na obra The Fable of the Bees. O diálogo se intitula Primeiro diálogo entre Horácio e Cleomenes: “Assim, a maior parte das paixões são consideradas como fraquezas, e comumente chamadas de fragilidades. Enquanto elas são os próprios poderes que governam toda a máquina. E, sendo isso percebido ou não, determinam ou antes criam a vontade que imediatamente precede toda ação deliberada." (MANDEVILLE, online. Tradução minha). Poderíamos ainda citar, de Mandeville, o texto chamado Uma Investigação sobre a Origem da Virtude Moral. Logo na introdução nosso autor diz: “(...) acredito que o homem (além de pele, carne, ossos etc., que são óbvios ao olhar) é um conjunto de várias paixões, as quais o governam alternadamente, à medida que são provocadas e vêm à tona." (MANDEVILLE, online) Na nota 'C' da Fábula das Abelhas, pode-se ler: "Caso o homem tivesse em igual medida tanto a razão quanto o orgulho, ele nunca ficaria lisonjeado com elogios aos quais ele tem consciência de que não os merece". (MANDEVILLE, online. Tradução minha).

${ }^{26}$ Ver o capítulo IV do livro de Luiz Roberto Monzani (2011, pp.73-133).

LEITE, Rafael de Araújo e Viana. Debate transformado em querela: panorama sobre a relação entre o luxo e as paixões. Griot 
que havia transcorrido sem grandes perturbações. Para citar um exemplo comprobatório desse recrudescimento, mais de 100 textos sobre o luxo foram escritos de 1736 a $1786^{27}$. Muitos deles fazendo a sua apologia. Pela primeira vez na história desse debate os detratores ficaram na posição do contra-ataque. Temos agora uma discussão com características de querela.

Bernard Mandeville, como já foi adiantado, foi o autor da primeira e talvez mais polêmica apologia do luxo. Existem um aspecto dessa defesa para os quais gostaria de chamar atenção brevemente. A teoria das paixões que sustenta a defesa do luxo e a antropologia que está nela ancorada. Mandeville aborda o tema do luxo de uma maneira sintomaticamente distinta da tradição de moralistas antigos como Sêneca. Para ele, o conceito de ataraxia seria impraticável. A natureza humana não poderia se submeter a ditames estritamente racionais em que as paixões exerceriam um papel negativo, atuando predominantemente como obstáculos para uma conduta desejável-racional.

Em acordo com Mandeville, seríamos movidos primeiramente por apetites, como fome e luxúria (Remark $R$, online), contudo, saídos da primeira infância nos mostraríamos eminentemente passionais, isto é, todas as criaturas humanas seriam suscetíveis de raiva, medo, vergonha e elogios, para ficar com poucos exemplos ${ }^{28}$. Os homens sem paixões, dirá nosso autor, seriam como que moinhos de vento colocados onde não existe ar (Remark $Q$, online). Sua antropologia parece pressupor as paixões dotadas de uma força incontornável. Mais do que isso. Elas são essenciais às pessoas.

Jean-François Melon, seguindo a perspectiva mandeviliana, foi responsável por uma forte apologia do luxo. Em seu Essai politique sur le commerce, de 1734, especificamente no capítulo IX, o autor trata do luxo. Melon parece estar familiarizado com os argumentos de Mandeville. Sua antropologia indica isso. Para ele, as pessoas são prioritariamente seres movidos por paixões não tendo, portanto, como guia principal de sua conduta a razão. Além disso, Melon defende que a legislação de um Estado não deve abafar, mas sim fazer com que as paixões se tornem benéficas para a comunidade:

Se os homens fossem tão felizes, para que assim regulassem suas ações de acordo com as máximas da religião, eles não teriam necessidade de leis. $O$ dever serviria de freio para o vício e estímulo para a virtude. Mas, infelizmente para nós, somos subjugados por nossas paixões, e a legislação deve se esforçar somente para direcioná-las de modo a serem vantajosas para a comunidade (MELON, 1734, p. 173\174, online. Tradução minha).

Reviravolta importante. Na esteira de Mandeville e usando uma argumentação que não será estranha a Voltaire, Jean-François Melon segue mostrando que o luxo é uma inclinação natural dos homens. A tese é clara: quem

\footnotetext{
27 Ver o artigo de Jeremy Jennings The debate about luxury in eighteenth-and nineteenth-century french political thought (2007, p. 83). Ver também o livro de Luiz Roberto Monzani (2011, p. 25/26).

28 Após a publicação do poema The Grumbling hive, Mandeville escreveu uma obra maior em que desenvolve a posição apresentada no poema. Além de acrescentar um introdução, diálogos e ensaios a obra intitulada The fable of the bees apresenta uma série de notas (remarks) explicando e detalhando trechos do poema.
}

LEITE, Rafael de Araújo e Viana. Debate transformado em querela: panorama sobre a relação entre o luxo e as paixões. Griot : Revista de Filosofia, Amargosa/Bahia, v.17, n.1, p.33-47, junho/2018. 
tem acesso à abundância vai invariavelmente desejar usufruí-la ${ }^{29}$. A própria definição de luxo passa a ser colocada em questão. O que, de fato, ele é? É possível identificá-lo objetivamente? O que era considerado luxuoso em certo tempo, devido à raridade de recursos, não necessariamente será considerado como tal em outro recorte histórico ${ }^{30}$. Em uma mesma sociedade, uma camisa pode ser vista tanto como luxuosa (par ao camponês) quanto como necessária (para um dono de fábrica) por causa do grau distintos de riqueza entre as pessoas. Do ponto de vista político, o luxo deve ser estimulado. $O$ Estado deveria permitir que ele fosse alcançado pelo esforço individual das pessoas desde que isso aconteça pelas vias legais ${ }^{31}$.

Estamos diante de uma antropologia nova, responsável não só por reabilitar paixões consideradas comumente prejudiciais, mas também por alçá-las a motores do progresso artístico e social. A busca por prazer, desde que não vá de encontro à legislação passa a ser vista, da mesma forma, como legítima.

Voltaire, por sua vez, propõe uma antropologia que está fortemente ligada à obra de Mandeville e Melon. Todas as pessoas apresentariam algumas características universais, como o instinto de auto conservação, amor-próprio, razão, piedade e orgulho. Essas paixões não são vistas como problemáticas. Pelo contrário. Representariam as ferramentas necessárias, ofertadas pela natureza, para formarmos sociedade e nos desenvolvermos ${ }^{32}$. Para o que nos interessa, é preciso salientar que, sem acesso ao luxo, as pessoas passariam uma vida de miséria e atribulações. Reféns da natureza, sofreriam tanto quanto os civilizados podem gozar de comodidades:

Que seria do homem no estado que se denomina natureza pura? Um animal muito abaixo dos primeiros iroqueses que foram encontrados no norte da América (...) visto que estes sabiam acender o fogo e confeccionar flechas. Foram necessários séculos para se chegar a essas duas artes. (VOLTAIRE, 2008, p. 315).

Voltaire parece estar, na passagem citada, tomando o luxo em um sentido rigorista, visto que o homem natural, sem luxo, não possuiria nada que não fosse absolutamente necessário para sua sobrevivência. Em tais termos, se a manutenção do fogo e a produção de flechas dizem respeito às nossas comodidades porque aumentam a eficiência em relação à caça e preparação dos alimentos e, além disso, são resultado da sagacidade humana, elas podem ser entendidas como sendo luxuosas. Tudo o que foi inventado para facilitar nossa vida, que teve uma aparição

29 “Quem quer que se encontre possuidor de grande abundância, terá o desejo de aproveitar disso." (MELON, 1880, p. 174. Tradução minha).

30 "O que era luxo no tempo de nossos pais, é agora muito comum; e o que é luxo para nós, não o será para a nossa posteridade." (MELON, 1880, p. 174. Online, tradução minha).

31 “O luxo de uma nação, é restrito a mil homens em comparação a vinte milhões de outros que são tão felizes quanto eles, quando um bom sistema de governo possibilita que eles usufruam, calmamente, o fruto de seu trabalho. Se os lavradores e os artífices quiserem ser luxuosos, isso deve ser aceito, por causa do trabalho adicional que eles serão obrigados a cumprir." (MELON, 1880, p. 177. Online, tradução minha).

32 Ver o verbete 'Homem', do Dicionário filosófico: “Todos os homens que foram descobertos nos países mais incultos e mais assustadores vivem em sociedade como os castores, as formigas, as abelhas e várias outras espécies de animais." (VOLTAIRE, online. Tradução minha).

LEITE, Rafael de Araújo e Viana. Debate transformado em querela: panorama sobre a relação entre o luxo e as paixões. Griot 
histórica é, nesses termos, luxo. A conclusão é clara: o homem natural, desconhecendo o luxo, seria um animal rústico e pouco propício à felicidade ${ }^{33}$.

De obstáculo para a virtude, o luxo passa a ser entendido como uma tendência natural e legítima. São as paixões que nos levam a ele, e elas são compreendidas como essencialmente ligadas à nossa natureza, características que não podem ser abafadas. Contra os que detectam nelas um desenvolvimento histórico, seja pela interferência da sociedade, como quer Rousseau, ou mesmo uma punição divina por desobediência, como algumas religiões apregoam, Voltaire defende que o orgulho, a avareza e a inveja são naturais e exercem papel fundamental no advento e desenvolvimento da sociedade. Além de gerarem o luxo, cultura e artes, a avareza ou o desejo por bem-estar pessoal, por exemplo, acabariam otimizando os cuidados para com as técnicas que possam ser úteis para nós, e isso promove as artes: "Essa intensa vontade de adquirir os bens da terra acrescentava todos os dias novos progressos a todas as artes." (VOLTAIRE, 2001, p. 79) ${ }^{34}$.

O luxo favoreceria as artes assim como os espíritos inventivos e as descobertas científicas. De suscetível que as pessoas eram em relação ao meio em que viviam, com a sua ajuda, passam a reger o mundo, estudando a natureza cuidadosamente para atingirem bem-estar. A busca por prazer é, portanto, um dos motores do progresso. Voltaire, contudo, poderia ser criticado por analisar o luxo unicamente por uma perspectiva prática. Ele não se aprofunda na questão da desigualdade de fortunas. Levado por sua argumentação, o leitor quase não enxerga problemas em relação à difusão do luxo. Para ele, não haveria muito o que se fazer em relação à desigualdade social senão se esforçar para não a tornar excessivamente radical. Lemos no verbete 'Igualdade': “É impossível, neste mundo infeliz, que os homens que vivem em sociedade não sejam divididos em duas classes, uma de opressores, outra de oprimidos. Essas duas classes se subdividem em mil outras e essas mil apresentam ainda características diferentes." (VOLTAIRE, online).

Para concluir, vimos como a defesa do luxo, tal qual apareceu no século XVIII, apoiou-se no desenvolvimento de uma nova antropologia, segundo a qual as paixões não podem ser simplesmente abafadas em nome de uma conduta racional. A

\footnotetext{
33 Ver o verbete 'Homem” do Dicionário filosófico: “(...) abandonado à natureza pura teria como linguagem apenas alguns sons inarticulados (...) não teria tampouco conhecimento de Deus e da alma, bem como da matemática. Suas ideias estariam reduzidas ao cuidado de alimentar-se. A espécie de castores seria preferível." (VOLTAIRE, online. Tradução minha).

${ }^{34} \mathrm{O}$ orgulho, quando bem direcionado, poderia garantir a obediência às leis ou regras comuns, o que permite o estabelecimento de uma sociedade. Todos os homens querem reconhecimento por parte de seus semelhantes. Sendo assim, se o legislador conferir recompensas para ações que trazem vantagens à comunidade, ou seja, se o preço da glória for o sacrifício em nome do bem público, os homens farão isso em busca de reconhecimento - ou ao menos - fingirão fazê-lo. Voltaire escreve no Tratado de Metafísica: “O orgulho, sobretudo, é o principal instrumento com o qual se construiu esse belo edifício da sociedade. Tão logo as necessidades reuniram alguns homens, os mais sagazes dentre eles se aperceberam de que todos esses homens tinham nascido com um orgulho indomável (...) Não foi difícil persuadi-los de que, se fizessem para o bem comum da sociedade algo que lhes custasse um pouco de seu bem-estar, seu orgulho seria plenamente ressarcido. Bem depressa, portanto, se passou a distinguir os homens em duas classes: a primeira, dos homens divinos que sacrificam seu amor-próprio ao bem público; a segunda, dos miseráveis que só amam a si mesmos: todo mundo quis e quer ser ainda da primeira classe, conquanto todo mundo seja, no fundo do coração da segunda (...)" (VOLTAIRE, 2001, p. 78).
} 
busca por prazer, nesse quadro conceitual, passa a ser estimulada e vista como algo positivo. Elementos que estabeleceram um terreno fértil para que fosse proposta mais de uma apologia do luxo que se apropria de uma argumentação econômica, mas também moral e política em favor da busca por bem-estar. 


\section{Referências bibliográficas}

AQUINO, Tomás de. Suma Teológica. Segunda parte - Questões 123-170. Trad. Alexandre Correia. São Paulo: Linográfica Editora, 1958.

BARBINI, Giuseppe. Il lusso: La civilizzazione in un dibattito del XVIII secolo. Padova: Cleup. 2009.

BAUDRILLART, H. Histoire du Luxe Privé et Public depuis l'antiquité jusqu'a nos jours. Tome premier. Paris: Librairie Hachette, 1880.

HERÓDOTO. História. Trad. J. Brito Broca. Ediouro. 2001.

JENNING, Jeremy. The debate about luxury in eighteenth- and nineteenth-century French political thought; In: Journal of history of ideas. Vol. 69. Number 1, pp. 73$105,2007$.

LA BRUYÈRE. Os caracteres. Trad. João de Barros. Lisboa: Editora Sá da Costa, 1956.

LAÉRCIO, Diógenes. Lives of Eminent Philosophers. Trad. E. D. Hicks. Volume II, books VI-X. London: Harvard University Press, 2005.

MANDEVILLE, Bernard. Fable of the Bees: or Private Vice, Publick Benefits. With a Commentary Critical, Historical, and Explanatory by F. B. Kaye. First Volume. Oxford: Clarendon Press, 1924. Disponível em: http://oll.libertyfund.org/titles/mandeville-the-fable-of-the-bees-or-private-vicespublick-benefits-vol-1. Último acesso realizado em: $11 \backslash 08 \backslash 2017$.

MELON, Jean-François. Essai Politique sur Le Commerce: Colection des Principaux Economistes, tome I, Economistes Financiers du 18 siècle. Disponível em: http://gallica.bnf.fr. Último acesso realizado em $02 \backslash 05 \backslash 2015$.

MONTAIGNE, Michel de. Ensaios. Trad. Sérgio Milliet. Col. Os Pensadores. São Paulo: Abril Cultural, 1980.

MONZANI, Luiz Roberto. Desejo e Prazer na Idade Moderna. São Paulo: Ed. Unicamp, 1995.

PLATÃO. A República. Trad. J. Guinsburg. São Paulo: Difusão europeia do livro, 1965.

PLUTARCO. Vidas dos homens ilustres. Trad. Aristides da Silveira Lobo. Tomo 1, Teseu-Rômulo; Licurgo-Numa; Sólon-Publícola. São Paulo: Editora das Américas, 1951.

ROUSSEAU, Jean-Jacques. Oeuvres completes. Tome III. Paris: Pleiade, 1964.

SÊNECA, Lúcio Aneu. Cartas a Lucílio. Trad. J. A. Segurado e Campos. Lisboa: Calouste Gulbenkian, 2001.

Consolação a minha mãe Hélvia. Trad. Agostinho da Silva. Col. Os

Pensadores. São Paulo: Abril Cultural, 1973.

TROUSSON, Raymond. Art et luxe au dix-huitième siècle. On line. Acessível pelo site: http://www.bon-a-tirer.com/volume42/rt.html. Último acesso realizado em 03/11/2012.

VOLTAIRE. Dictionnaire philosophique. Disponível em: http://artflsrv02.uchicago.edu/cgi-bin/philologic/navigate.pl?toutvoltaire.699.

Último acesso realizado em $06 \backslash 08 \backslash 2017$.

LEITE, Rafael de Araújo e Viana. Debate transformado em querela: panorama sobre a relação entre o luxo e as paixões. Griot 
Défense du mondain. Disponível em: http://artflsrv02.uchicago.edu/cgibin/philologic/getobject.pl?c.261:1:1.toutvoltaire. Último acesso realizado em $06 \backslash 08 \backslash 2017$.

Le mondain. Disponível em: http://artflsrv02.uchicago.edu/cgibin/philologic/getobject.pl?c.261:1.toutvoltaire. Último acesso realizado em $06 \backslash 08 \backslash 2017$.

O Filósofo Ignorante. Antonio de Pádua Danedi. São Paulo: Martins Fontes, 2001.

Observations sur MM. Jean Lass, Melon et Dutot sur le Commerce, le Luxe, les Monnais, et les Impôts. Disponível em: http://artflsrv02.uchicago.edu/cgibin/philologic/getobject.pl?c.290:1.toutvoltaire. Último acesso realizado em $06 \backslash 08 \backslash 2017$.

Tratado de Metafísica. Trad. Antônio de Pádua Danesi. São Paulo: Martins Fontes, 2001.

Autor(a) para correspondência: Rafael de Araújo e Viana Leite, Universidade Federal do Paraná, Faculdade de Filosofia, Ciências e Letras, R. Gen. Carneiro, 460, CEP 80060-150 - Centro, Curitiba PR, Brasil.rafael_vianaleite@hotmail.com 